\title{
An outline of the tectonic evolution of China
}

Tectonically China is composed of three Precambrian continental platforms, Sino Korea, Yangtze. Tarim, and possibly also Cathaysia. With their interstitial fold belts, they were incorporated together to form part of the Eurasian Supercontinent through the Indosinian orogeny in the late Triassic. In addition, there are the northern border of the Indian Platform, the Himalavas and the northern massifs of Gondwanan affinities, which were accreted or collaged successively onto the Eurasian Supercontinent in post-Indosinian times. Nine tectonic domains are recognised, which are delimited by major geosutures called convergent crustal consumption zones. The tectonic development was in five megastages daring which were formed: firstly, continental nuclei (c. $2.8 \mathrm{Ga}$ ); secondly; the proto-platforms (c. $1.8 \mathrm{Ga}$ ): thirdl: the platforms (c, $800 \mathrm{Ma}$ ); fourth/y, the Eurasian supercontinent (c.210 Ma), and fifthly, the present frame of China. Among these, the platform formation at the end of the Jimningian orogeny ( $800 \mathrm{Ma}$ ) and the superontinent formation at the end of the Indosinian orogeny 210 Ma) are the main landmarks.

\section{The tectonic frame and crustal development of China}

\section{Terminology of tectonic units}

A tectonic unit of the first rank, here called a tectonic domain, is a plate of composite structure and prolonged history of development. The boundaries between plates. here called convergent crustal consumption rones, are the main geosutures. The recent loose usage of the very useful term 'terrane' to cover tectonic units from continental platforms to single thrust masses has ciased some confusion. In order to make the tectonic terminology more systematic, we use a four-rank hierarchy in the hope that ambiguity may be avoided:

1 Tectonic domains composed of a continental platform and its surrounding fold belts, or of a group of Precambrian massifs interconnected by Early Palaeozoic fold zones so as to form a more or less integrated whole (Wang, 1981, 1986). The tectonic domains are delimited from each other by convergent crustal consumption zones ( $C Z$ ) that mark the final convergence of the opposite continental margins.

2 Platforms (cratons) and mobile belts.

3 Units within a platform that comprise ancient continental nuclei and Precambrian basement of various ages, and those within a mobile belt attributable to a single continental tract, made up of fold zones of various ages with or without median massifs. The fold zones and massifs originate from successively accreted island ares and fragments split from the continent: they are usu- ally bounded by subduction zones (here called accretional crustal consumption zones, or $\mathrm{AZ}$ ).

4 Terranes within the fold zones. These might be regarded as special cases of the third rank:

Three ranks of tectonic stage may be discerned (Wang, 1982). The first is mainly of a global nature and denotes profound changes in the geospheres and in world tectonic frames. The second is the traditional tectonic stage, in which there were important changes in tectonic trames or patterns. The third refers to epochs of intense orogenic deformation and magmatic activily. Five megastages are recognised, which led to the formation of

1 continental nuclei (c. $2.8 \mathrm{Ga}$ );

2 continental protoplatforms (c. $1.8 \mathrm{Ga}$ );

3 continental platiorms (c. $800 \mathrm{Ma})$ :

4 supercontinents (c. $208 \mathrm{Ma}$ ), and

5 disintegration of the supercontinent to form the present earth frame.

The main features and geological events in the different teetonic stages of China are summarised in Table 1. For convenience of discussion. we have specially included Korea in Figures 1 and 2 .

Nine principal tectonic domains may be recognised in China (Wang et al., 1990). They are from north to south (Figure 1):

1 The Altai-Hingan Belt (AHB), which is the southern part of the Siberia-Mongolia Domain.

2 The Junggar. Tianshan Belt (JTB), which is the eastern part of the Kazakhstan Domain (KZD).

3 The Burcya-Jamus Belt (JBB), which is the southern part of the North-east Asian Domain. All the three domains are composed of small massif groups interconnected by Early Palaeozoic fold zones and are delimited from each other by Early Hercynian convergent zones, the Ertix-Kalameili (EKCZ) in the west and the Hegen (HGCZ) in the east.

4 The Tarim Domain (TAD), which includes the unusually mobile platform and surrounding Palacozoic fold belts.

5 the Sino-Korea Domain (SKD) is surrounded mainly by Early Palaeozoic fold belts with several detached Precambrian massifs in the south. The boundary between the TAD and the SKD is controversial, as the Qaidam (Qd) and the Alxa $(\Lambda x)$ massifs seem to be closely related to both domains. A recent study (Wang, T, 1994) has discovered an ophiolite zone, the Enger Usu (EUCZ), which may be a convergent zone effectively delineating a southern (SKD) and a northern (KZD) faunal province during the Palaeozoic. This boundary between the SKP and the KZD is truncated by the Altun transcurrent fault in its western segment (Figure 1). The southern boundary of the platform in Korea is also problematic, because the cratonic area south of the Imjingang and north of the Ocheon Belt belongs certainly to the SKP not the YZP as generally believed (Yin et al., 1993). This interpretation seems to be supported by the indentation of the north-eastern part of the YZP into Korea along the Imjingang River during or after the Indosinian Stage (Figure 1). The northern boundaries of the TAD and the SKD are marked by the South Tianshan -Mazongshan convergent zone (TMCZ) and the Suolun- Linxi convergent zone (SLCZ) respectively, both of Late Hercynian age. Evidence for collision is not manifest for the SI CZ, but biogeographic evidence seems to be convincing (Huang, B. 1991; Li et al., 1992).

6 The Yangtze--Qiangtang Domain (YQD) includes the Yangtze Platform in the east and a group of massifs in the west, comprising the North Qiangtang (Qt), the Qamdo $(\mathrm{Qm})$ and the lincang-Simao (LS), which were probably parts of the YZP that 
Table 1 Tectonic stages in the crustal evolution of China.

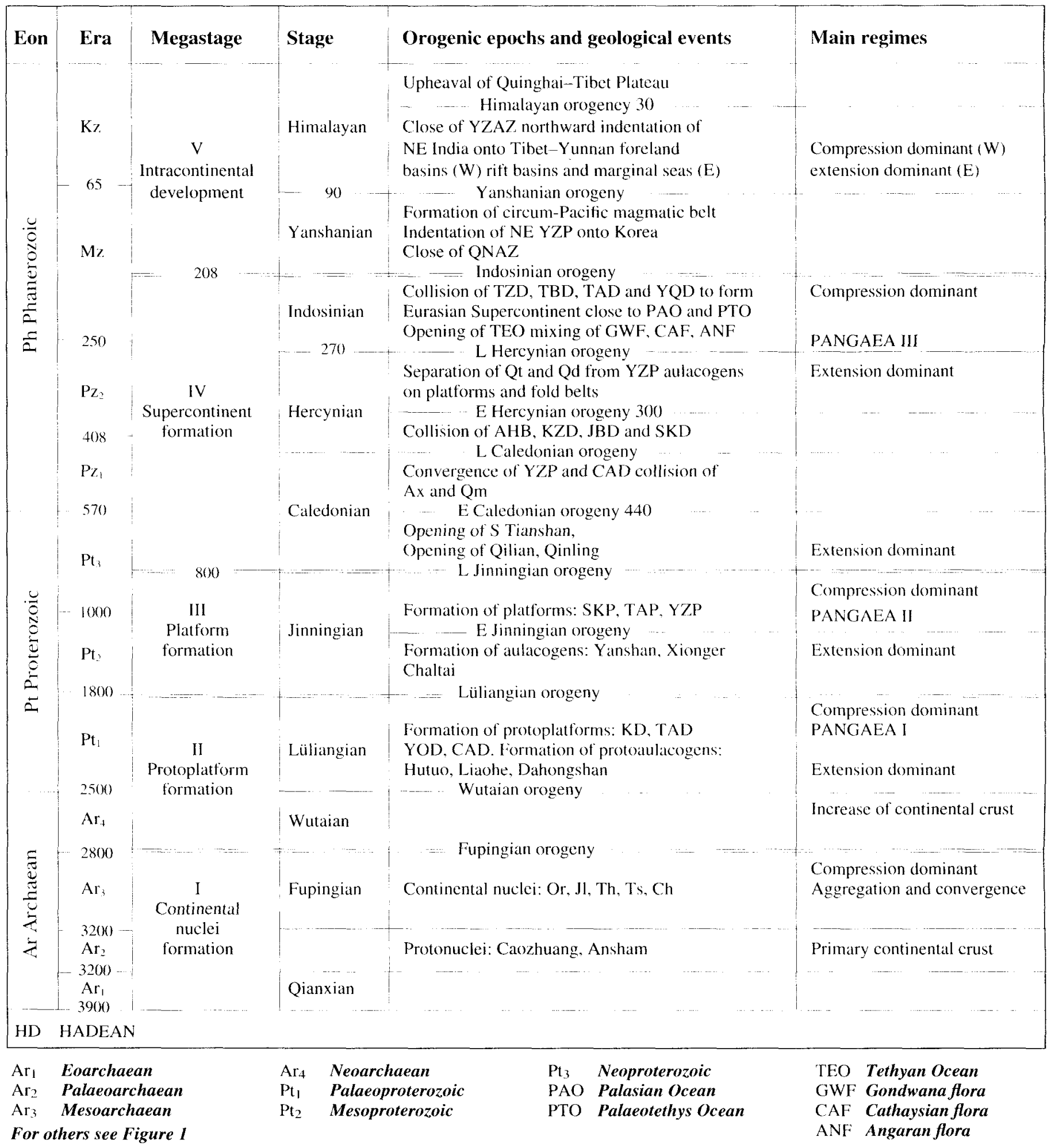

were detached and disseminated in the Late Palaeozoic (Wang et al., 1990). The YQD is demarcated from the northern domains by the Indosinian convergent zones, the Xiugou-Maqin (XMCZ) in the western, and the Fengxian-Tongcheng (FXCZ) in the eastern segment, but it is not clear how they were joined with each other in the south Qinling region. The position of the southern boundary of the YQD in northern Tibet has remained unclear, but recent studies have revealed that an oceanic basin, beginning in the Devonian or earlier and closed in the Late Permian, may be represented by the Longmucuo-Shuanghu convergent zone (LSCZ) (Li, 1987). The Changning-Menglian (CMCZ) zone to the west of the Lancang River in western Yunnan represents the southern continuation of the LSCZ and is proved to have closed at the end of Indosinian Stage (Liu et al., 1994). These convergent zones mark the southern limit of the Eurasian Supercontinent formed at the end of Indosinian Stage (Chang et al., 1992). 


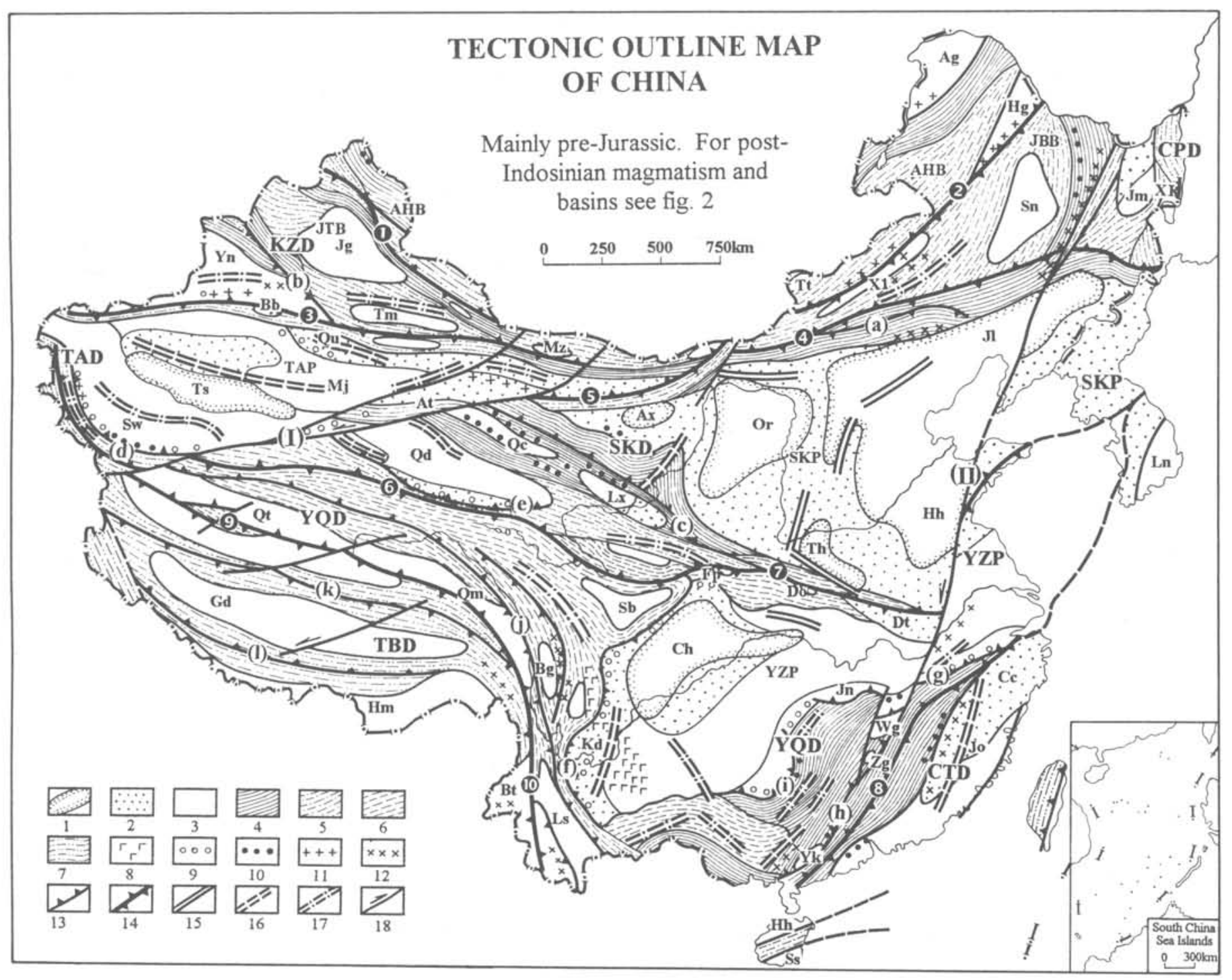

Figure 1

1 Continental nuclei, 2800 $\mathrm{Ma}\left(\mathrm{Ar}_{3}\right)$

2 Protoplatforms, $1800 \mathrm{Ma}\left(\mathrm{Pt}_{\mathrm{I}}\right)$

3 Platform and massifs $800 \mathrm{Ma}\left(\mathrm{Pt}_{3}\right)$

4 Caledonides

5 Hercynides

6 Indosinides

7 Yanshanides and Himalayaides

8 Permian basalts

9 Jinningian $\left(\mathrm{Pt}_{2-3}\right)$ granitic zones $(J)$

10 Caledonian $\left(P_{z_{1}}\right)$ granitic zones $(C)$

11 Hercynian $\left(\mathrm{Pz}_{2}\right)$ granitic zones $(\mathrm{H})$

12 Hercynian-Indosinian $(\boldsymbol{P}$ T) granitic zones

13 Accretional crustal consumption zones (AZ)

14 Convergent crustal consumption zones $(\mathrm{CZ})$

$15 \mathrm{Pt}_{2-3}$ aulacogens and rifts

$16 \mathrm{Z}-\mathrm{O}$ aulacogens

17 D-T aulacogens

18 Strike-slip faults, mostly post-Indosinian.
Tectonic units:

AHB Altai-Hingan Belt:

Ag Arguna Massif

$\mathrm{Hg}$ northern Hingan Massif;

Tt Tuotuoshan Massif

JBB Jamus-Bureya Belt:

Jm Jamus Massif

Sn Songnen Massif

XI Xilinhot Massif.

KZD Kazakhstan Domain:

Yn Yinnin Massif

Jg Junggar Massif

Tm Turpan-Hami Massif.

TAD Tarim Domain:

TAPTarim Platform:

Ts Central Tarrim Nucleus

Sw South-western Region

Mj Manjyar Region

Qu Quruktagh Region

At Altun Region

Bb Bayanbluk Massif

Mz Mazongshan Massif.

SKD Sino-Korea Domain:

SKP Sino-Korea Platform:

Or Ordos Nucleus
JI Jiliao Nucleus

Hh Hehuai Nucleus

Th Taihua Nucleus

Ax Alxa Nucleus

Qc Central Qilian Massif

Lx Longxi Massif

Qd Qaidam Massif.

YQD Yangtze-Qiangtang Domain:

YZPYangtze Platform:

Ch Chuanzhong Nucleus

Kd Kangdian Region

Kd Jiangnan Region

Dt Dabie-Tongbe Massif

Do Douling Massif

Fp Fuping Massif

Qt Qiangtang Massif

Qm Qamdo Massif

Bg Batang Massif

Sb Songpan-Bikou Massif

Ls Lincang-Simao Massif

Wg Wugong Massif

$\mathrm{Zg}$ Zhuguang Massif

Yk Yunkai Massif.

CTD Cathaysian Domain:

Cc Chencai Massif

Jo Jianou Massif
Ln Lingnan Massif

Hn Hainan Massif

Ss South China Sea Massif.

TBD Tibet-Burma Domain:

Gd Gangdise Massif

Hm Himalaya Massif

Bt Baoshan-Tengchong Massif.

CPD Circum-Pacific Domain:

Xk Xingkai Massif,

CZ Convergent zones:

1 EKCZ Ertix-Kalameili (H)

2 HGCZ Heganshan (H)

3 TMCZ South Tianshan

-Mazongshan $(\boldsymbol{H})$

4 SLCZ Soulun-Linxi $(H)$

5 EUCZ Enger Usu (H)

$6 \mathrm{XMCZ}$ Xüugou-Maqin (I)

7 FTCZ Fengxian

-Tongcheng (I)

8 SSCZ

Shaoxing-Shaoguan (C)

$9 \mathrm{LSCZ}$

Longmucuo-Shuanghu (I)

$10 \mathrm{MCZ}$ Changning-

Menglian (I).
AZ Accretional zones:

(a) OSAZ Ondor Sum (C)

(b) AXAZ Aibihu-XingXingxia $(\boldsymbol{H})$

(c) QQAZ North Qilian-North Qinling (C)

(d) KWAZ West Kunlun (J)

(e) KEAZ East Kunlun (J)

(f) LHAZ LongmenshanHonghe (J)

(g) SCAZ Shexian-Changsha $(J)$

(h) WYAZ Wugong-Yunkai (C)

(i) SBAZ Sibao (J)

(j) JTAZ Jinshajiang-Tengtiaohe (I)

(k) BNAZ Banggong-Nujiang ( $\mathrm{YH})$

(1) YZAZ Yarlung Zangbo $(Y H)$.

(J Jinningian; C Caledonian; H Hercynian;

I Indosinian; YH Yanshan-

ian-Himalayan)

SF Strike-slip faults:

(I) Altun;

(II) Tanlu. 
7 The Cathaysian Domain (CTD), formed of Precambrian massits incorporated in the Early Palaeozoic, and thus comparable with the KZD, was probably a part of the South-east Asian palaeocontinents. The relation between the $Y Z P$ and the CTD has long heen discussed (Guo et al. 1989). It seems doubtless that a widespread Precambrian basement existed in south China to the south of the Y7.P in Proterozoic time, which became somewhat dissociated and collided with the YZP in the Early Palaeozoic. The convergent zone between the $Y Z P$ and the CTD is tentatively drawn from Shaoxing to Shaoguan (SSCZ). It continues further to the south.

8 The Tibet-Burma Domain (TBD), occupying the northern border parts of the Indian Platform. consists of the Himalayas Massif (Hm), the Gangdise Massif (Gd) and the southern Qiangtang area, which are demarcated by the Yarlung Zangbo (YZAZ) and Bangong-Nujiang (BNAZ) ophiolite zones. The Indosinian Massif seems to be related to both the YQD and CTD, and the South China Sea Massif (Ss) may bear a closer relationship with Australia

9 The Circum-Pacific Domain (CPD), which includes the Xingkai Massif $\left(X_{k}\right)$ and the Yanbian area of north-east China. both came probably from the western Proto-Pacific and became collaged to east Asia in the Indosinian and later stages.

\section{China in Presinian times - the formation of continental nuclei, protoplatforms and platforms}

\section{Continental nuclei}

Continental nuclei of considerable size formed prior to $2.8 \mathrm{Ga}$ and occur in the Sino-Korea, the Yangtze and possibly the Tarim platforms. The oldest rocks are in the Jiliao Nucleus (JI) in eastern Hebei and Lianing, where detrital zircon, with a $\mathrm{U}-\mathrm{Pb}$ age of over $3.6 \mathrm{Ga}$, was obtained from the Huangbaiyu Quartzite, Jixian, and ancient granitic continental crust, 3.8 Ga old, was reported from Anshan, Liaming (Liu el al., 1992: Cheng, 1994), both of Eoarchaen ( $\mathrm{Ar}_{1}$ ) age (Table 1). Near Anshan. banded ironstone formations (BIF) of Algoman type were found unconformably overlying granites $2.8 \mathrm{Ga}$ in age. The Hehuai Nucleus (Hh) contains the Taishan Group repre. senting a granite-greenstone terrain, and the Taihua Nucleus (Th) contains both the Dengfeng granite-greenstone terrain and the Tai hua trondhjemite-tonalite-granodiorite (TTG)-type high grade terrain. Both of them contain rocks older than $2.8 \mathrm{Ga}$. The major part of the Ordos Nucleus (Or) subsided, but aeromagnetic data denote its ancient nature. and a latitudinal Mesoarchaean ( $\mathrm{Ar}_{3}$ ) granulite belt is distributed all along the Yinshan Range in the north. Another nucleus may be recognised in southern Alxa, where the basement contains granulites of presumably Mesoarchaean age. These nuclei formed the main grain of the ancient frame of north China and later coalesced to form the Sino-Korea protoplatform (Cheng et al., 1984).

The Central Tarim Nucleus (Ts) occupies a central position in the Tarim Basin. An isotopic age over $2.8 \mathrm{Ga}$ was recently reported from Archaean rocks in Quruktagh. On the Yangtze Platform the oldest rock is the Kongling TTG gneiss in the Gorges region which has an age of $2.8 \mathrm{Ga}$. This represents the upwarped border part of the Central Sichuan Nucleus ( $\mathrm{Sc}$ ), the Mesoarchaean age of which is suggested by the presence, in the Sanjiang area in south-eastern Guizhou, of detrital zircon, aged $2.8 \mathrm{Ga}$ and evidently of northern provenance. As indicated by the pronounced geochemical differences between the Taihua and Kongling rocks (Zhang et al., 1994) that constitute respectively the nuclei Th in the SKP and Se in the YZP. these two platforms were probably rather far apart from each other in the Archaean. On the whole, it seems reasonable to assume that they originated separately and were tater aggregated togethor to form the protoplatforms.

\section{Protoplatforms}

The Neoarchaean $\left(2.8-2.5\right.$ Gia. $\left.A r_{4}\right)$ in north China includes the Wutai, Luliang and Jiangxian groups in Shanxi and possibly the Dantazi Group in eastern Hebei, forming the so-called Eparchaean interval on the SKP. It is absent in many other areas. These mocks represent greenstone belts probably of extensional origin, and were intensely folded by the Wutatan orogeny and metamorphism 2.5 Ga), which marked a conspicuous cratonisation of north China. The succeeding Paiteoproterozoic $\left(\mathrm{Pt}_{1}\right)$ rocks comprise two tectono-sedimentary types, a rift-geosyncline type (Milanowsky. 1985) or protoaulacogen type (Wang and Qiao, 1984) and a semi-stable marine basin type. The first is represented by the Hutuo Group and its equivalents, containing clastics and argillites with metabasic rocks of bimodal pattern. The second is represented by the Songshan Group containing well sorted clastics and carbonates. Both were folded and metamorphosed during the Luliangian orogeny (Wang and Gao. 1984). Contempormeous rocks in Liaodong of north-east China include $\mathrm{Mg}$ carbonates and turhidites. sometimes attaining huge thicknesses. The Wutain and Luliangian orogenies caused the separated nuclei in north China to coalesce and led to the finat formation of the SK protoplatform. The southern boundary of the protoplatform was along the southern border of the Qining zone, which wa probably split and shifted to the south in the Mesoproterozole (Pin).

In northem Tarin. The Pt, Hinduag Group is variable in lithot. ogy and is in some places strongly folded and metamorphosed. partly to amphibolite facies. Contemporaneous rocks in Altun and west Kunlun show even stronger metamorphism. This represents the Luliangian orogeny which led to the formation of the Tarim protoplatform including the Yining ( $\mathrm{Yn}$ ) and Bayinbluk (Bb) massifs in central and south Tianshan. It is to be noted that the Meso- and Neoproterozoic sequences and lithology in northern Tarim, Alxa. Qaidam and north China are all similar to cach other, and the SinoKorea and Tarim protoplaforms may have been then interconnected. or at least close logether

Ancient crystalline basement in the Yangtze region is confined to the north of the Jiangnan Region (Jn), but the Dabie-Tongbai Massif (D) was probably a part of Yangtze in $\mathrm{Pl}_{1}$ time. The Dahong. shan Group in central Yunnan is a sodic alkali volcanic series and may represent a protoaulacogen formed on thin sialic crust on the inner side of the Kangdian Region (Kd). The Sibao Group, formerly thought to be $\mathrm{Pt}_{2}$ but recently proved to be $\mathrm{Pt}_{1}$ in age, marks the south-eastern boundary of the Yangtze protoplatform. although its metabasic content denotes a crust of transitional nature. In the $\mathrm{CTD}$ in south-east China (figure 1), isotopic ages over 2.5 Ga are known from Zhejiang and Fujian, and $\mathrm{Pt}_{1}$ basement rocks (Badu and Jianou groups) reaching amphibolite facies are well known (Dong of al. 1986), indicating the presence of an extensive ancient basement at that time. It is probable that at the end of $\mathrm{Pt}_{1}(1.8 \mathrm{Ga})$ the protoplaforms formed in China through the Luliangian orogeny had a wider extent than the present platforms. In fact, around 1.9-1.8 Ga, a pronounced increase of continental crust and a widespread cratonisation may have occurred, in China and probably all over the world, and the extensive protoplatforms that were formed may have joined with each other to form Pangaea ( Pangaea $I$ in Table 1). This is partly the reason why we prefer to put the lower boundary of Mesoproterozoic at 1.8 instead of $1.6 \mathrm{Ga}$ (Wang, 1986).

\section{Platforms}

The $\mathrm{Pt}_{2}$ and $\mathrm{Pt}_{3}$ rocks constitute paracover strata on a consolidated Sino-Korea protoplatform. The $\mathrm{Pt}_{2}(1.8-1 \mathrm{Ga})$ includes the Changchengian (1.8-1.4 Ga) and Jixianian (1.4 1.0 Ga) systems. The former comprises in the basal part aulacogen fuviatile deposits followed by clastics and carbonates containing some $\mathrm{K}$-rich volcanics in the Yaushan region. while the latter includes carbonates of wide transgression in the lower and of limited marine basin in the upper 
part (Sun et Lu, 1990). The lower part of Pt3 (Qingbaikouan $1000-800 \mathrm{Ma}$ ) represents true cover strata, but local deep trough filling reaching huge thicknesses occurs in Liaoning Province. At the close of the Qingbaikouan Period, general uplifting, coeval with the Jinningian orogeny, occurred and the Sino-Korea Platform was finally consolidated. Subsiding belts receiving marine deposits of Sinian (younger $\mathrm{Pt}_{3}$ ) age still lingered in the eastern part of the SKP.

Both the southern and the northern margins of the Sino-Korea protoplatform underwent a complicated history in $\mathrm{Pt}_{2}$ and $\mathrm{Pt}_{3}$ times. The Xionger aulacogen, with calc-alkali bimodal volcanics, may have been the interior failed arm of an tripartite rilting system brought about by the southward splitting and shifting of the Qinling zone. The resultant Kuanping marginal marine basin received sediments from both the northern passive margin and the southern Qinling island chain. It was the Jinningian orogeny that brought about the closure of the Kuanping basin and the northern accretion of the Qinling zone through an arc-continent collision (Zhang et al., 1994). The northern margin of the SKP was characterised by development of the mainly $\mathrm{Pt}_{2}$ marginal aulacogens, the inner Chartai belt and the outer Baiyun Obo belt. Disseminated minor massifs recently designated in Nei Mongol such as Xilinhot (XI) may represent border fragments that split off and moved to the north in the Neoprotero7oic.

The northern margin of the Tarim protoplatform has had a complicated history. In the western segment, the $\mathrm{Yn}$ Massif which was then still a part of the protoplatform, might have rifted away and reaccreted to the TAP again in the Jinningian, as is manifested by the presence of a blue schist $700-900 \mathrm{Ma}$ in age in the Aksu Group in northern Tarim (Xiao et al.. 1992). In the southern part of east Tianshan, the $\mathrm{Pt}_{2}$ Kawabulak Group may have been deposited on the northern passive continental margin facing an ancient ocean to the north. Along the northern border of the TAP a trough-like basin developed receiving very thick $P_{2}$ and $P_{t_{3}}$ clastics and carbonates almost devoid of volcanics, upon which was superimposed the Sinian Quruktagh aulacogen bearing volcano-sedimentaries and glacigene deposits. In the Ticklik region north of west Kunlun, the $\mathrm{P}_{2}$ and $\mathrm{Pl}_{3}$ strata are of a stable cover type, which marked the south ern limit of the platform. They seem to overlic the crystalline basement Karakash Group, although the contact relation has not been found. In west Kunlun, along the southern border of the ТАР. $\mathrm{Pt}_{3}$ granites of I-type are often met with, probably along the northern side of the West Kunlun Accretional Zone (KWAZ) of Jinningian age. $\mathrm{Pt}_{3}$ granites are also known in east Kunlun to the south of the Qaidam Massif ( Jiang el al., 1992), probably related to the east Kunlun Accretional Zone (KEAZ) (Figure 1). It seems that there was a northward subduction of oceanic crust on the southern side of the TAP and SKP during the Jinningian Stage.

In the Shenongiia region. near the norhern margin of the $Y Z P$, thick clastics and carbonates of $\mathrm{Pt}_{2}, 3$ age are developed. These represent aulocogen-type sediments indicating a rifted origin. The Dabie-Tongbai Massif ( $\mathrm{Dt}$ ) of $\mathrm{Ar}_{4}-\mathrm{Pt}_{1}$ age and the Douling Massif (D) of $\mathrm{Pt}_{1}$ age were probably rifted away from the Yangtze in $\mathrm{Pt}_{2}$, and the Wudang volcano-sedimentaries and its equivalents to the east may represent the rocks formed in the rifted troughs. To the west, the Precambrian Fuping Massif (Fp) may have been split from the Hannan region, the present northern border of the YZP. The newly generated oceanic crust was subducted southward under the $Y Z P$, and a clear subduction sequence of geochemically different granite zones has been observed in the Xixiang area (Gao et al., 1990). This evidently resulted from the Jinningian orogeny, after which the northern margin of the $Y Z P$ became passive. Along the western margin of the YZP. from Longmenshan to Honghe, the Neoarchaean Kangding Group and its equivalents, composed of amphibolites and migmatised gneiss of TTG type, and the $\mathrm{Pt}_{1}$ Dahongshan Group of metavolcanics and metasediments make up the western margin of the present platform. Further to the west, the Lingcang Simo Massif ( $L s$ ), bearing a basement formed of the Lancang Group of $\mathrm{Pt}_{1-2}$ age. was probably rifted away from the western (present orientation) margin of the $\mathrm{YZ}$ mother continent in $\mathrm{P}_{2}$ time. The subsequent eastward subduction of the newly formed oceanic crust resulting from this rifing, is indicated by the presence of $\mathrm{P}_{3}$ ophiolites near Ailaoshan (LHAZ) in the Honge Valley on the western margin of the YZP. Meanwhile, in the eastern part of the Kangdian Belt, a deep aulacogen developed receiving very thick volcanosedimentaries, the Kunyang and Yanbian groups of $\mathrm{Pt}_{2}$ age. These were intensely folded, and granites were extensively emplaced as a result of the Jinningian orogeny. Along the south-eastern margin of the $\mathrm{YZP}$ is the Jiangnan Region ( $\mathrm{Jn}$ ), which comprises a $\mathrm{P}_{2-3}$ arc and basin system that indicates a general eastward growth of continental crust (SCAZ and SBAZ). The north-eastern segment of the $J_{n}$ is complicated and Palaeozoic rocks were involved in a metamorphic belt generally designated as $\mathrm{Pt}_{2}$. . Nevertheless, there can be no doubt about the Proterozoic southern boundary of the platform. as Jinningian granites are extensively developed along the southern border of the YZP from southern Anhui to western Jiangxi.

The CTD, as pointed out previously, is comparable with the KZD, but, unlike the latter, no Late Proterozoic and Early Palaeozoic ophiolite zones have thus far been found. $\mathrm{P}_{2-3}$ metasediments and metavolcanics overlying the $\mathrm{Ar}-\mathrm{Pt}$, basement are widespread, but carbonates rarely occur. The $\mathrm{Pt}_{2,3}$ Baoban Group was recently found on the Hainan Massif ( $\mathrm{Hn}$ ) and in central and western Guangdong. Jinningian granites are reported from northern Zhejiang, and are cvidently the southern counterpart of the Jinningian collision granites along the southern border of YZP. It seems that during the Proterozoic, the YZP and CTD were probably separated from each other, although they became partly connected at their eastern parts through collision at the end of the Jinningian Stage

Summarising, at the close of the Jinningian Stage $(800 \mathrm{Ma})$, the SKP was probably more extensive than nowadays both to the north and south. and the northern margin was mainly of a passive and rifted nature. The Qd, Qc and Lx massifs in the south-west were still comnected with the Alxa region in the north, but the southern margin of $\mathrm{Qd}$ was probahly faced by an ancient ocean. The Qinling arc zone had reaccreted to the SKP through an arc-continent collision. To the east of the Tanlu strike slip fault, the boundary between the SKP and $Y Z P$ in Shandong is marked by the Jinningian granite zone. They probably collided with each other along this part of the boundary. The TAP was still connected with $\mathrm{Y}_{\mathrm{n}}$ in the north. but there were ancient oceans both to north of Kawabulak and to the south of Kunlun. The relationship between the SKP and TAP' is difticult to judge. The similarity of $\mathrm{Pt}_{2-3}$ stratigraphical sequences would put them together, but immediately after the Jinningian orogeny. in the Early Sinian. they seemed to have separated from each other, as manifested by palaeomagnetic data and by the different stratigraphical development in the Sinian. On the whole, at the close of the Jinningian Stage, the main platforms in China seemed not to be far apart from each other. This is supported by palacomagnetic studies recently carricd out by Zhang et al. ( 198.5 and afterwards), and an investigation of the global palaeomagnetic data seems to favour the idea of a Pangaca around 800-900 Ma (Pangaea II in Table 1) in the Early Neoproterozoic.

\section{China from the Sinian to the Triassic- the formation of supercontinents}

This megastage contains three tectonic stages, the Caledonian, the Hercynian and the Indosinian, the latter two usually not separable from each other, especially in south China. In the beginning of the Sinian, the principal platforms of China began to drift away from each other, and in the Cambrian and Ordovician the tectonic regime was essentially extensional. The close of the Calcdonian Stage brought about the reaccretion of the Qd to the SKP and the collision of the YZP with the CTD, but other intercontinental oceanic basins still remained. During the Late Hercynian and Indosinian orogenies the platforms and massifs were assembled together to form the Eurasian Supercontinent, which constituted the northern part of Pangaca III (Table 1). 


\section{The Caledonian Stage}

The Sino-Korean Platform was mostly exposed in the Early Sinian, only the eastern part being subsided. The Late Sinian glacigene deposits are distributed along the southern and western border of the platform, and are also known in northern Qd and northern TAP, indicating that these massifs were not far from each other at that time. Qd began to split away from the SKP in the Cambrian, first forming the north Qilian and then, in the Ordovician, the south Qilian oceanic basins. Ophiolite and ophiolitic melange zones are well developed in north Qilian. The oceanic basins began to shrink in the Late Ordovician and closed in the Late Silurian. Early Palaeozoic arc type volcanism is frequent and granites of both subduction and collision type are known on both sides of the Accretional Zone (QQAZ) from northern Qaidam in the south to southern Alxa in the north. The north Qilian Caledonides continue south-eastwards to north Qinling, where the oceanic basin was subducted under the SKP after the Ordovician (Zhang et al., 1988). Continental collision does not seem to have occurred, as only a few subduction-type Caledonian granites are found in north Qinling, and south Qinling regions. The complicated and rifted passive margin of the $Y Z P$, had mostly remained.

The SKP is bordered in the north by a narrow strip of Caledonides which contains Cambro-Ordovician island are volcano-sedimentaries, unconformably overlain by Late Silurian clastics and carbonates near the Ondur Sum accretional zone (UAAZ) (Tang et al., 1993). The south Tianshan oceanic trough to the north of the TAP was probably initiated in the Ordovician and persisted into the Late Palacozoic. Partial subduction may have occurred in SilurianDevonian time, which had caused the uplift of the TAP after its rifting and subsidence in the Cambrian and Ordovician, especially in the Manjyar region ( $\mathrm{Mg}$ ) (Figure 1). The narrow Caledonides belt bordering the Junggar and other massifs in northern Xinjiang is characteristic of the KZD. As the Silurian Tuvaella fauna was found both in the AHB of the Siberia-Mongolian Domain and in eastern Junggar of the Kazachstan Domain, these two domains were probably not separated by wide oceans in the Early Palacozoic.

As noted previously, the Jinningian orogeny brought about a partial collision of the YZP and the CTD in western Zhejiang and northern Jiangxi. Pan (in Liu ct al., 1993) thinks that these two massifs collided all along their margins, but later, oceanic troughs and basins formed between them by ritting in the Sinian, probably the result of strike slip faulting. He has drawn the boundary between the YZP and the CTD along the Qinfang residual seaway to the west of the Yunkai Massif (Yk). We, on the contrary, have interpreted the Yk and the $\mathrm{Wg}$ (via Yingyangguan) as marking the eastern margin of the $Y Z P$ from the presence of Sinian arc-type volcano-sedimentaries, and Lower Palaeozoic continental slope sediments found to the east of that line. This places the convergent zone (SSCZ) east of the Yk (Figure 1). In fact, the central Hunan-eastern Guangxi region was a back-arc basin with a transitional basement crust, and was not strongly folded in the Caledonian orogeny. The main belt of strong Caledonian magmatism and metamorphism runs from Wuyishan south-westwards to northem Guangdong. The Hainan Massif (Hn) was a constituent part of the CTD, but the South China Sea Massif (Ss) with an Australian affinity of Cambrian trilobites, was at that time still far away to the south. The Caledonian fold zone in northern Vietnam may indicate a closer relationship between the Indosinia Massif and the YZP, but that between the Indosinia and the South China Sea massifs remains unclear. Guo et al. (1989) and Chen et al. (1992) have both discussed the plate tectonics of south China in the Early Palaeozoic.

The Early Palaeozoic tectonic pattern in the Tibet-Yunnan Domain (TYD) is obscure. An analysis of the Ordovician and Silurian biogeography seems to indicate that the separated massifs ( $\mathrm{Hm}, \mathrm{Gd}, \mathrm{Bt}$ ) constituted an integrated whole and show close affinities with the YZP, but the Ordovician faunas show also similarities with those of the SKP. They were on the whole of Australian (Gondwanan) affinities (Yin ed., 1994).

\section{The Hercynian and Indosinian stages}

In the Late Palaeozoic, a major part of the SKP remained exposed from the time of its upheaval in the mid-Ordovician, until the Middle Carboniferous, when epicontinental seas began to inundate the east- ern and central part of the platform. Stable marine sediments prevailed up to mid-Permian time. when paralic and terrestrial deposits became predominant. The SKP had a passive northern margin in the Devonian, though Devonian deposits are absent inside the platform. An oceanic basin existed further to the north, which was consumed in the Early Carboniferous. This is manifested by the Hegenshan ophiolite zone ( $\mathrm{HGCZ}$ ), which marks continental collision between the SKD and the Siberia-Mongolia Domain for the first time. In the meantime, sea ways and marine basins still existed in the Soluon-Linxi belt, on the evidence of Permian turbidites and possible ophiolites, reported in the Linxi area near the SLCZ (Wang et al., 1991). Strong support for this view comes from biogeographic evidence. Not only were the Early Permian cool-warm water fauna and the Tethyan warm water fauna demarcated by this belt, but the line between Cathaysian and Angaran flora may also be traced from Daqingshan in the west to the Yanhian area in the east. The barrier disappeared in Late Permian, when the palaocontinents finally collided. Both the early Hercynian HGCZ and the late Hercynian SLCZ are significant, as the former marks the boundary between the AHB and JBB and the latter between the JBB and SKD.

In northern Xinjiang, collision between Altai and Junggar occurred along the EKCZ (Li et al., 1982). The convergent zone here has a complicated history and several en échelon ophiolite zones, the Almantai and the Kalameili, have been found (Xiao et al, 1992). The merging of Euamerican. Angaran and Cathaysian floras in northern Xinjiang in the Late Permian denotes the final assembling of the AHB. KZD and TAD into the Eurasian Supercontinent in the Late Hercynian.

A major part of the TAP underwent uplift after the Silurian. Devonian clastic terrestrial deposits were widespread on the platform and rifting and subsidence again prevailed in the Carboniferous. A marginal aulacogen, of Carboniferous age. was developed along the Kudi zone in north Kunlun and a strongly subsiding belt was formed in the south-western part of the platform (Figure 1). The collision between the south-castern border of the TAP and the western border of the SKD, including Qd in the south and Alxa in the north, (Figure 1), probably occurred along the Altun transcurrent fault and along the EUCZ, also in the Late Hercynian. In short, at the end of the Hercynian Stage, the oceanic basins between the northern continental masses, usually collectively known as the Palasian Ocean. had all disappeared, and the main oceanic basins in the south were part of Palaeotethys.

At the beginning of the Devonian, the northern marginal massits of the south Qinling region were quite near to the southern border of the SKP, and the marine basins in south Qinling actually received sediments partly from the north. The seas were shallow and narrow, as exaclly the same Devonian fish remains were found in Yunnan and Ningxia, north of the Gansu Corridor. The Late Palacozoic seaways on both sides of the northem marginal massifs of south Qinling were opened to the wide ocean in west Qinling, and extended eastwards along the southern border of the SKP (Wang, 1981), as proved by the recent discovery of Early Triassic open sea radiolarians to the north of the Tonghai Massif (Tb). This Late Palaeozoic and Triassic marine trough along the southern border of the SKP was finally closed during the Indosinian orogeny (FTCZ) (Wang, 1986).

At the end of Silurian, the YZP and the CTD had united in south China, and the only residual seaway was along the Qinfang belt, which was probably connected with the south-western oceans. In Devonian time, extensional conditions prevailed in the marginal parts of the YZP, especially in its western and south-eastern marginal tracts. The northern Qiangtang and Tangla massifs began to depart from the $Y Z P$, and rifting frequently occurred to form 'microaulacogens' in the Hunan-Guizhou-Guangxi region. Extensional processes were strengthened by Permian time, leading to profuse eruption of Permian and Triassic continental and submarine basalts and to the formation of rift-and arc-type volcanism in the limited oceanic basins in the triangular region of Songpan-Garze (Huang and Chen, 1987; Chang el al., 1992). To the west of the Jinshajiang, oceanic basins of considerable width existed on the eastern 


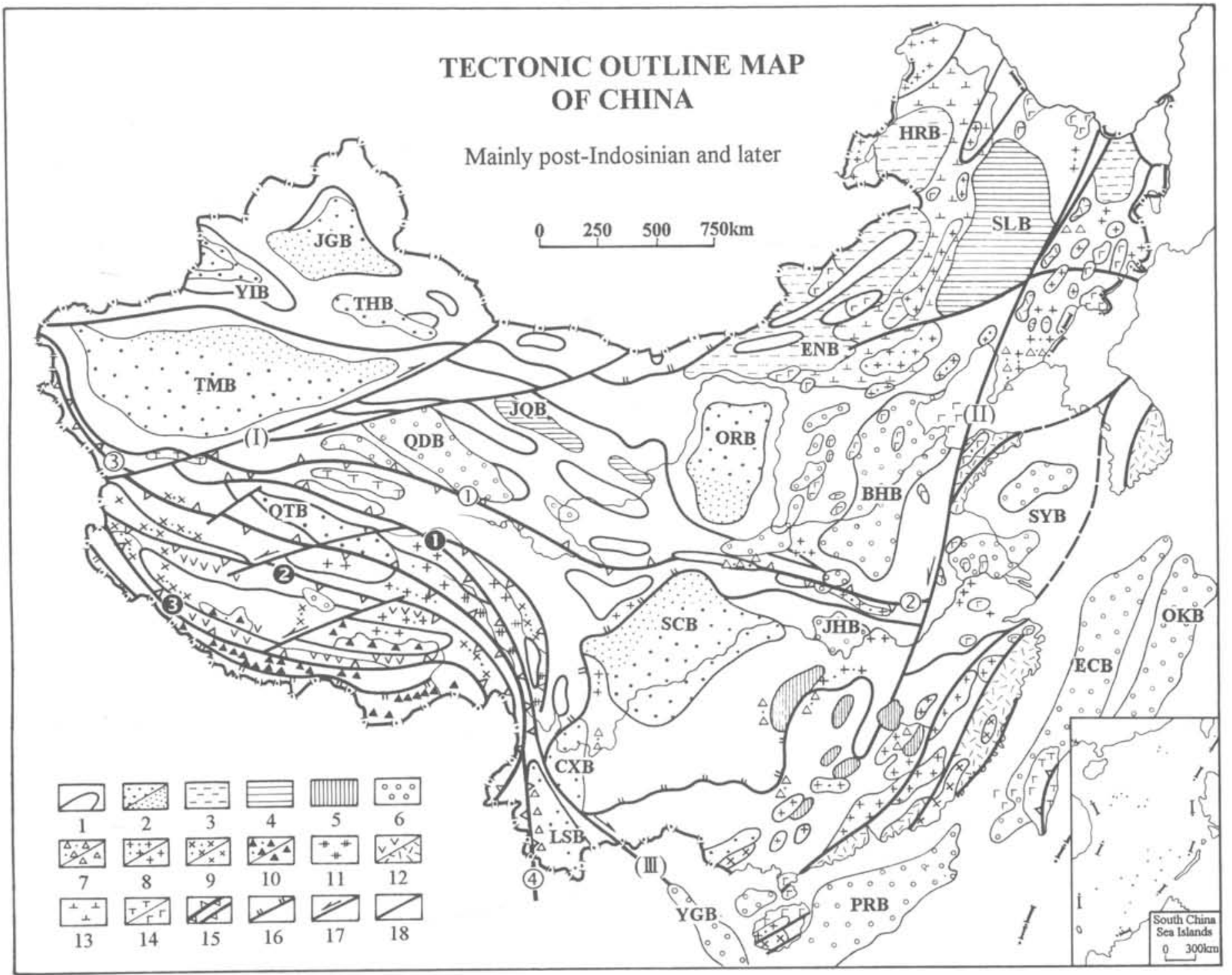

Figure 2

Continental platforms and massifs

Triassic-Cretaceous basins/foreland basins

Early Cretaceous (including Late Jurassic) basin group

Cretaceous basins

Late Cretaceous-Palaeogene basins

Palaeogene-Quaternary basins

Indosinian granites (I-type/S-type)

Early Yanshanian granites (I-type/S-type)

Late Yanshanian granites (I-type/S-type)

10 Late Yanshanian-Himalayan granites (I-type/S-type)

11 Indosinian calc-alkaline volcanic rocks

12 Yanshanian calc-alkaline volcanic rocks (andesite-dominant/rhyolite-dominant)

13 Yanshanian high-K volcanic rocks

14 Cenozoic volcanic rocks (high-K type basalts)

15 convergent zones/accretional zones

16 thrusts and nappes

17 strike-slip faults

18 faults in general.

JGB Junggar Basin

YLB Yili Basin

TMB Tarim Basin

THB Turpan-Hami Basin

QDB Qaidam Basin
JQB Jiuquan Basin

ORB Ordos Basin

SCB Sichuan Basin

SLB Songliao Basin

BHB Behaiwan Basin

JHB Jianghan Basin

YGB Yingehai Basin

SYB South Yellow Sea Basin

ECB East China Sea Basin

PRB Pearl Basin

OKB Okinawa Basin.

CZ Convergent Zones (open circles):

XMCZ Xiugou-Maqin

FTCZ Fengxian-Tongcheng

LSCZ Longmucuo-Shuanghu

CMCZ Changning-Menglian.

AZ Accretional Zones (black circles):

1 JTAZ Jinshajiang-Tengtiaohe

2 BNAZ Bangong-Nujiang

3 YZAZ Yarlung Zangbo.

SF Strike-slip faults:

(I) ATSF Altun; (II) TLSF Tanlu; (III) HHSF Honghe. 
side of the Qm and Ls massifs. The closure of these oceanic basins and the formation of Indosinian convergent zones (LSCZ and $\mathrm{CMCZ}$ ) to the south and west of Qt, Qm and Ls, marked the northward accretion of these massifs and the southern boundary of the newly formed Eurasian Supercontinent.

As mentioned previously, the major geosuture demarcating the Eurasian Supercontinent in the north and the Tibet-Burma Domain in the south has long been controversial. Early Permian tillites and cold water faunas indicating a Gondwanan origin are not found north of Longmucuo and Shuanghu. Typical Viséan faunas occur to the north of Gerze and a south Cathaysian flora of Late Permian age is found in Shuanghu. There seems little doubt about this main boundary, although the oceanic basin to the south of it may not have been so wide as previously thought (Wang. 1986). It may be noted in this context that, from a biogeographical and palaeomagnetic viewpoint, Palaeotethys, between the northern and the southern continents, seems not to have been wide enough for the palaeocontinents to be globally reconstructed. The presence of a Cathaysian flora in southwestern USA is also difficult to reconcile with our present knowledge of palaeophytogeography and palaeocontinent reconstruction.

\section{China in post-Indosinian times - intracontinental development}

\section{The tectonic framework at the close of the Indosinian Stage}

The close of the Indosinian Stage marks an important turning point in the tectonic evolution of China and led to the final formation of the Eurasian Supercontinent (Chang et al., 1988). The closure of Palaeotethys in the Late Triassic had left several convergent and accretional crustal consumption zones marked by ophiolite and ophiolitic melange zones of Indosinian age. The convergent zones include the Xiugou-Maqin (XMCZ), the Fengxian-Tongcheng (FTCZ) and its eastward extension in southern Shandong, the Longmucuo-Shuanghu (LSCZ) and the Changning-Menglian (CMCZ). The accretional zones comprise the Jinshajiang--Tengtiaohe (JTAZ), the Garze-Litang in Tibet and Yunnan. Almost every zone is accompanied by a magmatic belt, consisting of subduction- and collisiontype volcanic and granitic rocks aged from Late Permian to Late Triassic. These may be called coupled ophiolite-magmatic arcs (Mo et al., 1994). The formation of foreland type sediments in the western border parts of the Ordos and Sichuan basins in Late Triassic was also a manifestation of the Indosinian convergence events in the East Palaeotethys region (Figure 2 ).

\section{Post-Indosinian tectonic development of east China}

In the post-Indosinian, the tectonic development of the Chinese continent was chiefly controlled by interaction of the Siberian Plate from north, the Pacific Plate from east, and the Indian Plate from the south-west. The Palaeozoic tectonic regime was replaced and superimposed by the new regime which consists of a Circum-Pacific system in east China and a Tethys-Himalayan system in west China, the boundary lying roughly along longitude $105^{\circ} \mathrm{E}$ (Huang, 1978, Ren, 1990). With the exception of Tibet and western Yunnan and a few places including Taiwan (Juan, 1994) and the Nadanhada area of north-east China, where an ocean-arc-continent regime probably still existed, the major parts of China were under an intracontinental tectonic setting in post-Indosinian times.

The main post-Indosinian tectonic events in east China include the formation of the giant Circum-Pacific tectono-magmatic belt and of the extensive rift basin system. Intracontinental subduction and welding were also important, as the main platforms and most of the massifs had already been pieced together even before Indosinian time. Subduction is indicated by the development of Indosinian to
Yanshanian crust-derived muscovite-bearing granites in the Lower Yangtze region (Deng et al,, 1992), and by the presence of diamond/coesite-bearing ultra-high pressure metamorphic rock belt in the Dabie region. The time of high pressure metamorphism is controversial, but it was probably formed by the rapid Indosinian lithospheric convergence, and was brought to the surface by the Yanshanian uplift on the collapse of the orogenic belt. The A-type granites in Jilin-Heilongiiang region of north-east China probably had the same origin through the Indosinian orogeny followed by collapse of the orogenic belt.

In east China, the Yanshanian Stage was characterised by intracontinental collision and further welding of the main platforms and massifs. Thrust zones have long been known from the Yanshan region within the SKP, and more extensive thrust and nappe zones have recently been discovered to the north of the Langshan Range in Nei Mongol. The giant Tanlu transcurrent zone (Figure 1), the imbrication slices formed of Proterozoic strata in northern Anhui and the various thrust zones found in the lower Yangtze and central Hunan. were probably all formed at this time. The Yanshanian volcanic rocks and granitic intrusives in east China were mainly formed by intracontinental convergence and subduction; probably resulting from the distant, inland influence of subduction of the Kola-Pacific Plate beneath the Eurasian Supercontinent. They are distributed in three belts striking in a NE-SW direction as follows:

1 The Hingan-Yanliao magmatic belt consists mainly of $\mathrm{J}_{3}-\mathrm{K}_{1}$ (145-110 Ma) terrestrial volcanic rocks and granites of both Sand I-type, $130-95 \mathrm{Ma}$ in age, in the Daxinganling region, and of I-type, $138 \mathrm{Ma}$ in age, in the Yanliao region. Volcanic rocks range from calc-alkaline basalt-andesite association to intracontinental extensional hawaiite-trachyte-peralkaline rhyolite association. This change in rock association was coeval with the conversion from compressional to extensional conditions in the regional stress field of east China, after which the rift basins of north China were extensively developed (Ma et al. 1987).

2 The Changbai-Lower Yangtze magmatic belt stretching from Zhangguangcailing in the north to Nanling in the south mainly consists of $\mathrm{J}_{2}$ to $\mathrm{K}_{2}(169-85 \mathrm{Ma})$ high-potassium calc-alkaline andesite-dacite-rhyolite and shoshonite-mugearite-trachyte volcanic assemblages. The granites are of S-type in the Nanling Range, and of S-I-type in north-east China. The volcanics seem to have been formed in an active continental margin with relatively thick crust, as they show clear compositional polarity across the magmatic arc in the lower Yangtze region. The arc volcanism ceased at the end of Cretaceous owing to collapse of the subduction zone and was followed by rift-related basaltic volcanism (Deng et al., 1992). The granites in north-east China and Nanling region show little relation with the subduction of the Pacific Plate.

3 The coastal belt contains volcanic rocks ranging in age from $\mathrm{J}_{3}$ to $E_{1}$. They are $K_{1}-E_{1}$ in Okhotsk-Chukchi, $K_{2}-E_{1}$ in Sikhote-Alin-Laoyeling, $\mathrm{K}_{2}$ in southern Korea, $\mathrm{J}_{3}-\mathrm{K}_{2}$ in southeast China, with an eruptive peak in $K_{1}$ (Tao et al., 1988). A few andesite-dominant calc-alkaline volcanic rocks and I-type to I-S-type granites occurred in a very early stage. The main stage $\left(K_{1}\right)$ was dominated by rhyolite-dacite rocks and S-type granites. This is the well-known 'rhyolite chain' of the east Asian continental margin, which might have resulted from oblique subduction of the Kola-Pacific Plate against the Eurasian Supercontinent. Volcanism seems to have gradually shifted from south to north and from west to east with time. Bimodal volcanic associations and A-type granites formed in the Late Cretaceous indicate collapse of the orogenic belt and the beginning of intracontinental extension.

Since the Late Cretaceous, rifting and extension have prevailed in the eastern part of east China, which had led to the formation of rift basins and extensive eruptions of rift-related basalts. This seems to imply that an upwelling mantle plume was active beneath the continental lithosphere in east China. The principal rift basins in east China are mainly distributed in three belts: 
I A western belt including the Ordos and Sichuan basins which have a complicated history of development. They were cratonic sag basins in Permian to mid-Triassic, and became partly foreland basins in Late Triassic as a consequence of collision between the SKP and the YZP at the closure of the Palaeotethys. They had undergone alternating active and quiescent stages in the Jurassic and Cretaceous (Li et al.,1994), and came to an end at the close of the Mesozoic

2 A central belt comprising the Songliao, north China (Huabei) and Jianghan-Dongting basins, with filling ages ranging from Palaeogene to Quaternary, except the Songliao basin which was mainly Cretaceous. All these basins were formed under an extensional or transtensional regime and are characterised by rapid subsidence, thick basin-fill and relatively high heat flow. They show in general a superimposed architecture with an underlying rifting and an overlying thermal subsidence type of structure. The underlying thin crust $(24-40 \mathrm{~km})$ was probably coincident with an upwelling asthenosphere from depth. Hundreds of small fault-controlled basins are distributed along both the western and the central belts, which show to a certain extent similarities with the Basin and Range type of western North America.

3 A continental margin belt including the Yellow Sea and the East China Sea basins, and the marginal basins of South China Sea. Cretaceous basins with thick marine shales of pre-rifting age in the offshore area. The main rifting phase occurred in the Palaeo gene, and was followed by the Neogene post-rift depression forming asymmetric sediment drapes. The Pearl Basin and the Qiongdongnan Basin are representative of this type, whereas the tectonic characteristics of the Beibuwan Basin and the Yellow Sea Basin formed on a continental basement show similar characteristics to onshore rift basins. The main continental marginal basins of China were developed on basement of either continental or transitional crust (Liu ed., 1992).

As mentioned above, Cenozoic magmatic events are characterised by rift-related basaltic cruptions, whereas granites seldom occur in east China. Palaeogene tholeitic basalts are found beneath the sedimentary beds in most basins, and may imply a relatively fast spreading rate for the basins in the Palaeogene. On the contrary, the Neogene-Quaternary basalts are characterised by peridotite nodulecontaining alkali basalt series. They occur usually as individual volcano or volcano clusters, and probably denote continental rifting with a relatively slow spreading rate (Chi, 1988).

\section{Post-Indosinian tectonic development of west China}

The elimination of Palaeotethys and the formation of the Eurasian Supercontinent through the convergence of continental platforms and massifs, may imply that, in the Indosinian Stage. the vast region was controlled by a downward cold mantle flow in the decp part. In west China, the generation and evolution of Neotethys was the most important tectonic event in the post-Indosinian period. The Yarlung Zangbo oceanic basin, the main branch of Neotcthys. was probably initiated in Late Permian or Early Triassic, and was fully developed by the Late Triassic. A good suite of MORBs accumulated along with mafic-ultramafic rocks and overlying radiolarian cherts, and together with peridotites. The Banggong-Nujiang oceanic basin, another branch of Neotethys, probably opened in the Early Jurassic and an ophiolite suite comparable to the oceanic crustal sequence has also been found. The general dispersion of lithosphere and the generation of new oceanic crust were pronounced in west China from the Late Triassic to the early Cretaceous, and may indicate that an upwelling hot mantle plume was in action in the deep part. In both the Yarlung Zangbo and the Banggong-Nujiang oceanic basins subduction started in the Late Jurassic, ending in the Late Eocene and Late Cretaceous respectively. To the north of the Yarlung Zangbo zone, along the southern border of the Gangdise Massif (Ga), a conspicuous magmatic belt developed, consisting of calc-alkaline volcanic rocks and granites as well as molasse deposits. The elimination of Neotethys, the northward movement of the Indian Platform and its collision with the Eurasian Supercontinent in the Early Cenozoic marked a change from a divergent to a convergent tectonic condition in this region, and presumably a corresponding change from upward to downward, deep mantle convection.

The Cenozoic tectonic history of west China was essentially intracontinental convergence and subduction, and may be subdivided into two stages. The first stage is from Oligocene to Miocene and was dominated by strong horizontal compression and intracontinental subduction leading to the formation of the Himalayas and Gangdise mountain ranges and of the giant Siwalik and Indos-Yarlung Zangbo molasse zones (Li et al., 1986). The Main Central Thrust (MCT) and the large-scale nappe zone in the Himalayas were probably formed at this time. The remarkable crustderived muscovite-bearing granite belts (aged 40-10 Ma. mainly $20-10 \mathrm{Ma}$ ) in the Himalayas and partly in southern Gangdise provide strong evidence of intra-continental subduction. In the second stage from Pliocene to Quaternary, the main event was the quick differential uplift of the Qinghai-Xizang(Tibet) Plateau. Intracontinental subduction took place on both the southern and the northern margin of the plateau, and brought about the formation of the Main Marginal Thrust (MMT) of the Himalayas and of the north Tibet--south Kunlun-Hoh Xil volcanic belt. The latter consists mainly of a shoshonite series as well as a few high- $\mathrm{K}_{2} \mathrm{O}$ calc-alkaline volcanic rocks (Deng, 1991). The northward compression and upheaval of the plateau have given rise to the surrounding giant strike-slip faults such as the Altun and the Honghe (Figure 2 ). These processes have produced remarkable effects as far away as north-west China, including late Mesozoic and Cenozoic molasse zones developed in the Qaidam Basin and along the northern piedmont zone of the Kunlun and Qilian mountains. The development of foreland thrust belts in northern Tarim and in the Junggar and Turpan-Hami basins in north Xinjiang was the result of compressive forces acting from either side of the Tianshan Mountains.

\section{Concluding remarks}

1. China is a composite continent consisting of nine tectonic domains that were sutured together in different stages. There have been five megastages of tectonic evolution, among which the end Jinningian and Indosinian stages mark the most important changes in the tectonic regime.

2. Primary continental crust formed scattered proto-nuclei in the Eoarchaean mainly in north China. which coalesced into separate continental nuclei at the end of Mesoarchaean (2.8 Ga). The continental nuclei combined together. first at the end of Archacan and then in the Palaeoproterozoic ( $1800 \mathrm{Ma}$ ), to form extensive protoplatforms. The continental crust may have then attained its largest extent and formed a loosely united supercontinent, which might have been a part of Pangaea I (Table 1).

3. Extensional conditions manifested by aulacogens dominated in the Mesoproterozoic, and were followed by a mainly convergent regime in the Jinningian Stage, leading to formation of the mature platforms. The gathering of the platforms in China is consistent with the idea of a Neoproterozoic (c. $900-800$ Ma) supercontinent Pangaea II. Up to this time the tectonic evolution of China had been mainly the increase and stabilisation of the continental crust.

4. From the Sinian to the Triassic the tectonic evolution of China consisted mainly of the complicated development of continental margins by rifting, splitting and reaccretion of marginal massifs Generally known as the accordion model of continental margin development (Huang, 1984), this is to a certain extent consistent with Sengor's idea of crustal growth (1993) on the southern margin of the Siberian craton. On the whole, extension prevailed in the Caledonian, and compression in the Late Hercynian and Indosinian stages, bringing about formation of the Eurasian Supercontinent. A similar course may have occurred in most parts of the world resulting in the appearance of Pangaca III. 
5. The close of the Indosinian Stage saw profound changes in the tectonic regime of China, and the latitudinal (present orientation) tectonic grain developed in the Palacozoic was replaced by a Tethyan system in west China and a Pacific system in east China. The post-Indosinian was tectonically mainly intracontinental except in the Tibet-Burma Domain. Continental collision, subduction and indentation of the massifs prevailed as the three surrounding plates, India, Siberia and Pacific. interacted.

6. Analyses of the magmatism, tectonics and palaeomagnetism in post-Indosinian times seem to indicate that there was an alternating series of extensional and compressional regimes in time both in west China and in east China, and that in the same period, west China and east China were contrary in regard to their extensional or compressional conditions. This may mean that a convection system in the upper mantle was operating at depth below the Chinese continent, with altemating up- and down-welling current in space and time. Furthermore, from a macrocosmic point of view, the more-or-less periodical change between compressional and extensional conditions in China and the seemingly recurrent appearance of Pangaea may reflect a higher order periodic change engendered by processes in the interior of the earth which were under cosmological control. 7. In this paper, we have in general followed plate tectonics theory. However, there are problems for plate tectonics theory as it now stands. In particular:

- there is a comparative lack of evidence for ancient large oceans and deep ocean deposits prior to the Mesozoic;

- there are discrepancies in global reconstructions of palaeocontinents (the large gaps in eastern Tethys and between Siberia and north China in the Late Palaeozoic are well known) and

- there are difficulties in the biogeographical interpretation of Cathaysian flora in south-western North America.

Tomographic studies of the upper mantle (Woodhouse et al.. 1984) have revealed the downward extension of seismic waveforms to over $300 \mathrm{~km}$, which would put some constraints on plate motions. Therefore it is probably necessary to investigate the extent of free motion of the cratonic lithospheric plates and to determine whether the earth's radius has increased in the geological past (Owen, 1992). If the earth's radius has increased up to around $15 \%$, presumably in an episodic pulsatory and asymmetric way (Milanovsky, 1983), the discrepancies mentioned above may be reconciled. at least 10 a certain extent.

\section{Acknowledgements}

We are thankful to Cheng Yuqi, Deng Jinfu. Dong Shenbao, He Guoqi, Li Sitian, Li Tingdong, Liu Beipei, Liu Hefu, Ren Jishun, Sun Shu, Yang Zunyi and Zhang Benren for fruitful discussions and to Shi Xiaoying, Li Xiang and Zhao Yudong for help in various ways. The references had to be very concise, and it is impossible to list all the papers and publications consulted.

\section{References}

* in Chinese with English summary, others in English

Chang, Chengfa, and Bian, Q. 1992, The multi-branched orogenic complex of the Indosinides: nature and evolution of Palaeotethys: Advances in Geoscience (2), Contributions to the 29th IGC, 1992, Kyoto, Japan. China Ocean Press, pp. $1-8$

Chen, $X u$ and Rong, J, 1992, Ordovician plate tectonics of China and its neighboring regions, in Webby, B D and Lauric, J R eds., Global Perspectives on Ordovician Geology, pp.277-291.

* Cheng Yuqi, chief ed., 1994, The regional geology of China: Geological Publishing House, Beijing, 507 pp.

Cheng, Yuqi, Sun, D, and $W u_{1} J, 1984$, Evolutionary megacycles of the Early Precambrian Proto-North China Platform: Journal of Geodynamics, v. 1. Pp. $251-277$.

*Chi, Jishang ed., 1988, The study of Cenozoic basalts and the upper mantle of eastern China: China University of Geosciences Press, Wuhan, $277 \mathrm{pp}$
*Deng, Jinfu, Yie, D, Thao, H. and Tang, D, 1992. Volcanism, deep internal processes and basin formation in the lower reaches of the Yangtze River: China University of Geosciences Press, Wuhan, 184 pp.

*Deng Wanming, 1991, The geology, geochemistry and ages of shoshonitic volcanic rocks in the Middle Kunlun orogenic belt: Scientia Geologica Sinica, 1991, no. 3, 201-213.

*Dong, Shenbao (S P Tung) et al., 1986. Metamorphism in China and its Relalion with crustal evolution: Geological Memoirs. ser. 3, no. 4, 230 pp.

Gao Shan. Zhang B. and Li, Z, 1990, Geochemical evidence of Proterozoic continental arc and continental margin rilt magmatism along the northern margin of the Yangtze Craton, south China: Precambrian Research, v. 47, pp. 205-221.

Guo Lingzhi, Shi, Y, Lu, H, Ma. R, Dong, H, and Yang, S. 1989, The PreDevonian tectonic patterns and evolution of south China: Journal of Southeast Asian Earth Sciences, v. 3, no. 1-4, pp.87-93.

Huang, Benhong. 1991, Biogeography of Late Palaeozoic floras of northeastern China, in Ishii, K, et al., eds., Pre-Jurassic geology of Inner Mongolia, China, pp. 159-174.

Huang, Jiqing, 1978, An outline of the tectonic characteristics of China: Eclogae Geologicae Helvetia, v. 71, no. 3, pp.611-635.

Huang, Jiging, 1984, New research on the tectonic characteristics of China: Colloqia K05, Tecionics of Asia, 27th International Geological Congress, Moscow.

Huang, Jicjing, and Chen, B, 1987, The evolution of Tethys in China and adjacent regions: Geological Publishing House, Beijing, $109 \mathrm{pp}$.

* Jiang, Chunfa, Yang, J, Feng, B, Zhu, 7. et al., 1992, Opening and closing tectonies of Kunlun Mountains: Geological Memoirs ser. 5, no. 12, 224 pp.

Juan, V C, 1994, Tectonic history of Taiwan: Journal of the Geological Soci cty ol China, v. 37 , no. 1, pp. $1-6$.

* Li Cit, 1987. The Longmucuo-Shuanghu-Langcangjiang plate suture and northern boundary of distribution of Gondwana facies of Permo-Car boniterous systen in northern Xi/ang, China: Journal of Changehun College of Geology, v. 17, no. 2, pp. 155-166.

Li, Chunyu, Wang, Q, Liu, X, and Tang, Y, 1982, Tectonic map of Asia $(1: 8000(K)(0)$ and its explanantory notes: Cartographic Publishing House. Beijing.

I, Silian, Yang, S, and Jerrykiewic, T, 1994, Upper Triassic-Jurassic foreland basin sequenes of the Ordos Basin in China, in Stratigraphic Evolution of Foreland Basins: SEPM Special Publication no. 52.

Li, Tingdong, Xiao, X, Li, G, Gao, Y, and Zhou, W, 1986, The crustal evolution and uplift nechanism of the Qinghai-Xizang Plateau: Tectonophysich, v. 127, pp.279-289.

I.i, Xingxue, and Shen, G, 1992, Permian phytoprovincialism in the Far Fast: Palatentological Socicty of Korea Special Publication no. 1, pp.1-26.

* Liu, Baojun and $\mathrm{X} u, \mathrm{X}$, eds. Evolution of the sedimentary basins and their litho facies-palacogeography of south China: Science Press, Beijing, 236 pp.

Iiu, Benpei. Feng, Q, and Fang, N, 1991, Tectonic evolution of the Palaeotethys in Changning-Menglian belt and adjacent regions, western Yuman: Journal of China University of Geosciences, v. 2, pp. 18-28.

Liu, D, Y, Nutman. A, T, Compston, W, Wu. J, S, and Shen, Q, H,1992, Remnant of $>3800$ Ma crust in the Chinese part of the Sino-Korcan Craton: Geology, v. 20, pp.339-.-342.

Liu, Guangding, ed., 1992, Map series of geology and geophysics of China and adjacent regions: Geological Publishing House, Beijing.

Mal, Xingyuan and Wu, D, 1987, Cenozoic extensional tectonics in China: Tectonophysics, no. 133 , pp.243-55.

Milanovsky, E E, 1983, Major stages of riting evolution in the earth's history: Tectonophysics, v. 94, pp.599-607.

Mo, Xuanxue, Deng, J and Lu, F, 1994, Volcanism and the evolution of Tethys in Sanjiang area, southwestern China: Journal of Southeast Asian Earth Sciences, v. 9, no. 4, pp.325-334

Owen. H G, 1992, Has the earth increased in size? in Chatterjec, S. and Hotton III, N, eds., New concepts in global tectonics: Texas Technical University Press, Lubbock, pp.289-296.

*Ren, Jishun, Chen, T, Niu, B, Liu, Z, and Liu, F, 1990, Tectonic cvolution and mineralization of the continental lithosphere in eastern Chind and adjacent regions: Science Press, Beijing, $205 \mathrm{pp}$.

Sengor, A M C, Natalin, B A, and Burtman, V S, 1993, Evolution of the Altaid tectonic collage and Palacozoic crustal growth in Eurasia: Nature, v. 364, pp. $299-307$.

Sun, Dazhong and Lu, S, 1990, Tectonic evolution of the Proterozoic in the North China Platlorm: in Naqui, S M, ed., Precambrian continental crust and its economic resources: Development of Precambrian Geology, v. 8 , pp.503-522.

Tang, Kedong and Yan, Z, 1993, Regional metamorphism and tectonic evolution of the Inner Mongolian suture zone: Journal of Metamorphic Geology, v. 11, pp.511-522. 
*Tao, Kuiyuan, 1988, The Basic characteristics of the Mesozoic volcanism in the coastal region of southeast China: Bulletin of the Nanjing Institute of Geology and Mineral Resources, no. 9, pp.12-30.

${ }^{*}$ Wang, Hongzhen, 1981, Geotectonic units of China from the viewpoint of mobilism: Earth Science-Journal of Wuhan College of Geology, 1981, no. I, pp. $42-66$.

*Wang, Hongzhen, 1982, The main stages of crustal development of China: Earth Science-Journal of Wuhan College of Geology, 1982, no. 3, $155-177$.

Wang, Hongzhen, and Qiao, X, 1984, Proterozoic stratigraphy and tectonic framework of China: Geological Magazine, v. 121, no. 6, pp.599-614.

Wang, Hongzhen, 1986, Geotectonic development of China, in Yang, Zunyi, Cheng, Y, and Wang, H, The geology of China: Clarendon Press, Oxford, pp. $235-275$.

*Wang, Hongzhen, Liu, B, and Li, S, 1990, Geotectonic units and tectonic development of China and adjacent regions, in Wang Hongzhen et al., Tectonopalaeogeography and palaeobiogeography of China and adjacent regions: China University of Geosciences Press, Wuhan, pp.3-34.

Wang, Quan, and Liu, X, 1991, Pre-Jurassic tectonic evolution between Cathaysia and Angaraland in Inner Mongolia of China, in Ishii, $\mathrm{K}$ et al., eds., Pre-Jurassic Geology of Inner Mongolia, China, pp.99-112.

Wang, Tingyin, Wang, S, and Wang, J, 1994, The formation and evolution of Palaeozoic continental crust in Alxa Region: Lanzhou University Press, Lanzhou, China, 213pp.

Woodhouse, J H, and Dzievonski, A M, 1984, Mapping the upper mantle: Three dimensional modeling of earth structure by inversion of seismic waveforms: Journal of Geophysical Research, v. 89, pp.5953-5986.

*Xiao, Xuchang, Tang, Y, Feng, Y, Zhu, B, Lin, J, and Zhao, M, 1992, Tectonic evolution of northern Xinjiang and its adjacent regions: Geological Publishing House, Beijing, I69 pp.

Yin, An and Nie, S, 1993, An indentation model for the North and South China collision and the development of the Tanlu and Honam fault systems, eastern Asia: Tectonics, v. 12, no. 4, pp.801-813.

Yin, Hongfu, ed, 1994, The palaeobiogeography of China: Oxford University Press, $370 \mathrm{pp}$.

*Zhang, Guowei, et al., 1988, Formation and evolution of the Qinling Orogenic Belt: Northwest University Press, Xi'an, 192 pp.

Zhang, Huimin and Zhang, W, 1985, Palaeomagnetic data, Late Precambrian magnetostratigraphy and tectonic evolution of eastern China: Precambrian Research, v. 29, pp.65-75.
Zhang, Benren, Luo, T, Gao, S, Ouyang, J, Han, Y, and Gao, C, 1994, Geochemical constraints on the evolution of North China and Yangtze blocks: Journal of Southeast Asian Earth Sciences, v. 9, no.4. pp.405-416.

Dr Hongzhen Wang is a professor of the China University of Geosciences (Beijing) and a member of the Chinese Academy of Science. He was formerly the President of the Palaeontological Society of China, and has specialised in coral palaeontology, palaeogeography and Precambrian geology. Presently, he is engaged in the study of sequence stratigraphy of China and on the reconstruction of palaeocontinents. $\mathrm{He}$ is also interested in the history of geology and is a Vice-President of INHIGEO, IUGS.

Professor Xuanxue Mo is Dean of the Graduate School, China University of Geosciences. He has undertaken studies on igneous petrology. volcanology and tectonics, especially on Tethyan tectonomagmatic analysis, in Tibet and adjacent regions, and on Cenozoic peridotitebearing basalts in eastern China.
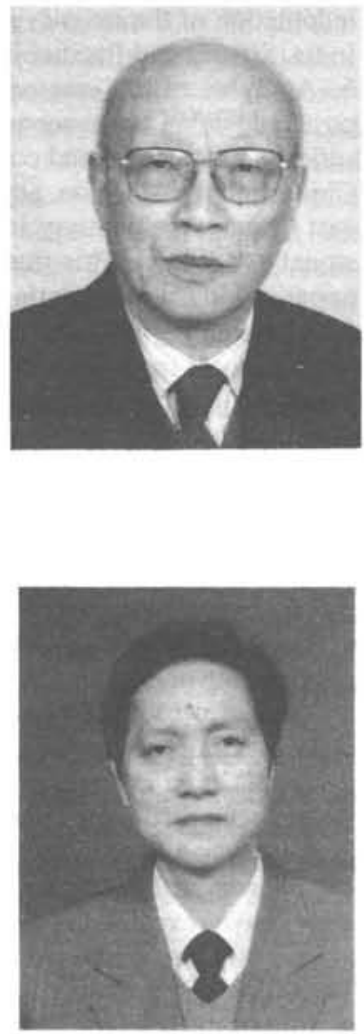